\title{
THE INFECTION OF CALVES BY ENDOPARASITES IN CALVING PENS AND CALF HOUSES
}

\section{J. BEJSOVEC}

Department of Biological Sciences in Animal Production, University of Agriculture, 16521 Praha 6 - Suchdol

Received August 6, 1984

\author{
Abstract \\ $\mathrm{B}$ e $\mathrm{j}$ o $\mathrm{v}$ e c,J.: The Infection of Calves by Endoparasites \\ in Calving Pens and Calk Houses. Acta Vet.Brno, 55, 1986: 197-206.
}

Calves are infected with coccidia and helminths as early as during postparturient treatment, sucking and licking. Their mothers and the nurse cows are the source of infection. In calving pens operating for a longer period, $97.7 \mathrm{z}$ of the mothers excreted coccidia, $82.8 \mathrm{z}$ and $60.7 \mathrm{z}$ excreted the strongly pathogenic species Eimeria zuernii and $E$. bovis, resp., and $41.3 \%$ excreted helminth ova. In calving pens and calf houses operating for several years, 42.27 of the calves excreted coccidia: $26.9 \mathrm{z}$ $E$. zuernii, $21.7 \% E$. bovis and $2.8 \%$ helminth eggs. The contamination was studied of the newly bullt houses before their opening. After housing in the new calving pen, $88.4 \mathrm{z}$ of the first-calvers excreted coccidia and $16.3 \%$ helminth eggs. In the new calf house, $36.4 z$ and $10.6 z$ of the calves excreted coccidia and helminth eggs, respectively. Thirteen days af ter establishment in the new large-scale calf house, the percentage of calves parasitized with coccidia and helminths was very high, $72.8 \mathrm{z}$ and $17.3 z$, respectively.

It is from the calving pens and calf houses that the various species of endoparasities spread, as the environment of the houses is very convenient for them. The strongly pathogenic species of coccidia were found in all the houses under study. Coccidia are transferred especially by the weak, older calves which are kept in the calf hoises for a longer time. If the technological and hygienic rules of the "all in - all.out" system of housing are observed, then the amount of the parasites is too small to evoke clinical symptoms, thus enabling the young calves to develop their own defence mechanisms. If hygiene is not observed, the amount of oocysts increases considerably, even to cause clinical coccidioses.

Cattle, calves, large herds of cattle, epizootiology, coccidia, helminths.

Very frequently there are considerable losses of calves after birth and after their transfer to large-scale calf houses after weaning. Their performance often decreases when they are transferred to calf houses where they are fed on starters At the age of three weeks to three months the calves are parasitized with coccidia. If we consider the developmental cycle of the endoparasites, their reproductive capacity and the ability to become infective in the external environment, then it is evident that the losses aight be associated also with the infection of the calves as early as in the calving pens and calf houses. Various diseases could thus spread to other categories of calves, especially in large herds. That is why we studied the transfer of the etfological agents of parasitoses under normal operation of the calving pens and calf houses.

\section{Materials and Methods}

The author Investigated the beginning of the infection of calves after birth. 
Table 1

Excretion of occysts of the less pathogenic species of coccidia and of helminth eggs by calves in calving pens and calf houses

\begin{tabular}{|c|c|c|c|c|c|c|c|}
\hline $\begin{array}{l}\text { Age of calves } \\
\text { days }\end{array}$ & $1-2$ & $3-4$ & $5-7$ & $8-10$ & $11-20$ & $21-30$ & $31-40$ \\
\hline $\begin{array}{l}\text { Eimeria } \\
\text { alabamensis }\end{array}$ & $\begin{array}{r}0.3 \\
0.5 \\
133\end{array}$ & $\begin{array}{c}0.4 \\
0.1 \\
33\end{array}$ & $\begin{array}{c}1.3 \\
0.9 \\
33\end{array}$ & $\begin{array}{l}1.2 \\
0.5 \\
66\end{array}$ & $\begin{array}{r}7.8 \\
4.3 \\
166\end{array}$ & $\begin{array}{l}19.6 \\
18.1 \\
866\end{array}$ & $\begin{array}{l}24.4 \\
14.1 \\
233\end{array}$ \\
\hline $\begin{array}{l}\text { Eimeria } \\
\text { auburnensis }\end{array}$ & & $\begin{array}{r}0.8 \\
0.4 \\
100\end{array}$ & $\begin{array}{c}0.8 \\
0.7 \\
33\end{array}$ & $\begin{array}{l}0.8 \\
0.2 \\
33\end{array}$ & $\begin{array}{c}1.5 \\
0.3 \\
33\end{array}$ & $\begin{array}{r}3.6 \\
1.8 \\
133\end{array}$ & $\begin{array}{l}13.3 \\
11.8 \\
66\end{array}$ \\
\hline $\begin{array}{l}\text { Eimeria } \\
\text { bukidnonensis }\end{array}$ & $\begin{array}{c}0.3 \\
0.1 \\
33\end{array}$ & $\begin{array}{r}1.7 \\
0.9 \\
133\end{array}$ & $\begin{array}{c}0.8 \\
0.7 \\
33\end{array}$ & $\begin{array}{l}2.0 \\
0.6 \\
33\end{array}$ & $\begin{array}{r}2.6 \\
1.6 \\
166\end{array}$ & $\begin{array}{r}8.9 \\
9.5\end{array}$ & $\begin{array}{r}20.0 \\
9.6 \\
66\end{array}$ \\
\hline $\begin{array}{l}\text { Eimeria } \\
\text { subspherica }\end{array}$ & & $\begin{array}{r}5.0 \\
12.5 \\
2200\end{array}$ & $\begin{array}{r}6.7 \\
4.6 \\
100\end{array}$ & $\begin{array}{r}6.1 \\
1.9 \\
100\end{array}$ & $\begin{array}{r}13.3 \\
9.7 \\
166\end{array}$ & $\begin{array}{l}16.9 \\
11.9 \\
533\end{array}$ & $\begin{array}{l}31.1 \\
14.8 \\
100\end{array}$ \\
\hline $\begin{array}{l}\text { Eimeria } \\
\text { wyomingensis }\end{array}$ & & & & & $\begin{array}{c}0.3 \\
0.1 \\
33\end{array}$ & & \\
\hline Capillaria spp. & & $\begin{array}{l}0.4 \\
0.1 \\
33\end{array}$ & $\begin{array}{c}0.8 \\
0.3 \\
33\end{array}$ & & $\begin{array}{c}0.7 \\
0.2 \\
66\end{array}$ & $\begin{array}{r}1.8 \\
1.4 \\
133\end{array}$ & $\begin{array}{l}4.4 \\
1.4 \\
33\end{array}$ \\
\hline $\begin{array}{l}\text { Haemonchus } \\
\text { contortus }\end{array}$ & & $\begin{array}{l}0.4 \\
0.1 \\
33\end{array}$ & $\begin{array}{r}0.4 \\
0.3 \\
66\end{array}$ & & & & $\begin{array}{r}2.2 \\
0.7 \\
33\end{array}$ \\
\hline $\begin{array}{l}\text { Oesophagostonum } \\
\text { spp. }\end{array}$ & & & & $\begin{array}{c}0.8 \\
0.2 \\
33\end{array}$ & $\begin{array}{r}0.3 \\
0.2 \\
66\end{array}$ & & \\
\hline $\begin{array}{l}\text { Strongyloides } \\
\text { papillosus }\end{array}$ & & & & $\begin{array}{c}0.4 \\
0.1 \\
33\end{array}$ & $\begin{array}{c}1.1 \\
0.5 \\
66\end{array}$ & $\begin{array}{r}3.6 \\
2.7 \\
100\end{array}$ & \\
\hline $\begin{array}{l}\text { Trichostrongylus } \\
\text { spp. }\end{array}$ & $\begin{array}{c}0.3 \\
0.1 \\
33\end{array}$ & & & & $\begin{array}{c}0.3 \\
0.1 \\
33\end{array}$ & & $\begin{array}{l}2.2 \\
0.7 \\
33\end{array}$ \\
\hline $\begin{array}{l}\text { Trichuris } \\
\text { spp. }\end{array}$ & & & $\begin{array}{r}1.7 \\
1.4 \\
33\end{array}$ & $\begin{array}{l}0.4 \\
0.1 \\
33\end{array}$ & $\begin{array}{c}0.3 \\
0.1 \\
33\end{array}$ & $\begin{array}{r}3.6 \\
3.5 \\
233\end{array}$ & $\begin{array}{l}6.6 \\
2.9 \\
66\end{array}$ \\
\hline $\begin{array}{l}\text { Number of calves } \\
\text { examined }\end{array}$ & 316 & 240 & 237 & 248 & 270 & 112 & 45 \\
\hline
\end{tabular}

Numbers in table indicate: 8 of calves excreting coccidia oocysts and egg helminths. Average number of cocysts (eggs) in 1 gram of faeces. Maximum number of ocysts (eggs) in 1 gram of faeces.

For better orientation in the table, the zero values were left out.

In young calves, usually no fecal examinations are carried out because the excretion of coccidia oocysts begins 6 to 22 days after infection (the prepatent period is yet uncertain in some species). Helminth ova and larvae are excreted later still. Many authors observed the transit of parasites through the alinentary tract of specific hosts. M a c k o $(1979,1980)$ e.g. found that a considerable amount of infective helminth eggs and larvae pass through the alimentary tract of specific hosts. B e $j$ o $v$ e $c$ (1983) observed a transit of coccldia oocysts in calves in the prepatent period after birth. In the very young calves, food passes through 
the alimentary tract relatively quickly. That 18 why the calves were examined coprologically beginning from the age of 20 hours. The qualitative flotation method after Breza (1957) was used as it 18 very effective and the quantitative method after B $\times z$ and $\zeta$ v a c (1967). More time was devoted to the examinations than to common, routine diagnosis.

In the new calving pen and new calf house recently put into operation, 43 wothers and 66 calves were examined. After introduction into the new large-scale calf house, 81 calves were exanined. In calving pens and calf houses which had been In operation for a longer time, 600 mothers, 200 nurse cows and 1468 calves were exanined.

\section{Results}

Calves begin to excrete coccidia from the first day of their life. At the age of one day, Eimeria zuernii, E. bovis, E. ellipsoidalis and $E$. alabamensis were found in $3.28,1.68,0.8 \%$ and $0.8 \%$ of the calves, respectively. At the age of two days, already $7.8 \%, 6.78,0.5 \&$ and $0.5 \&$ of the calves were shedding $E$. zuernii, E. bovis, E. ellipsoidalis and $E$. bukidnonensis, respectively. At the age of two days, helminth eggs appeared and in $0.5 \&$ of the calves

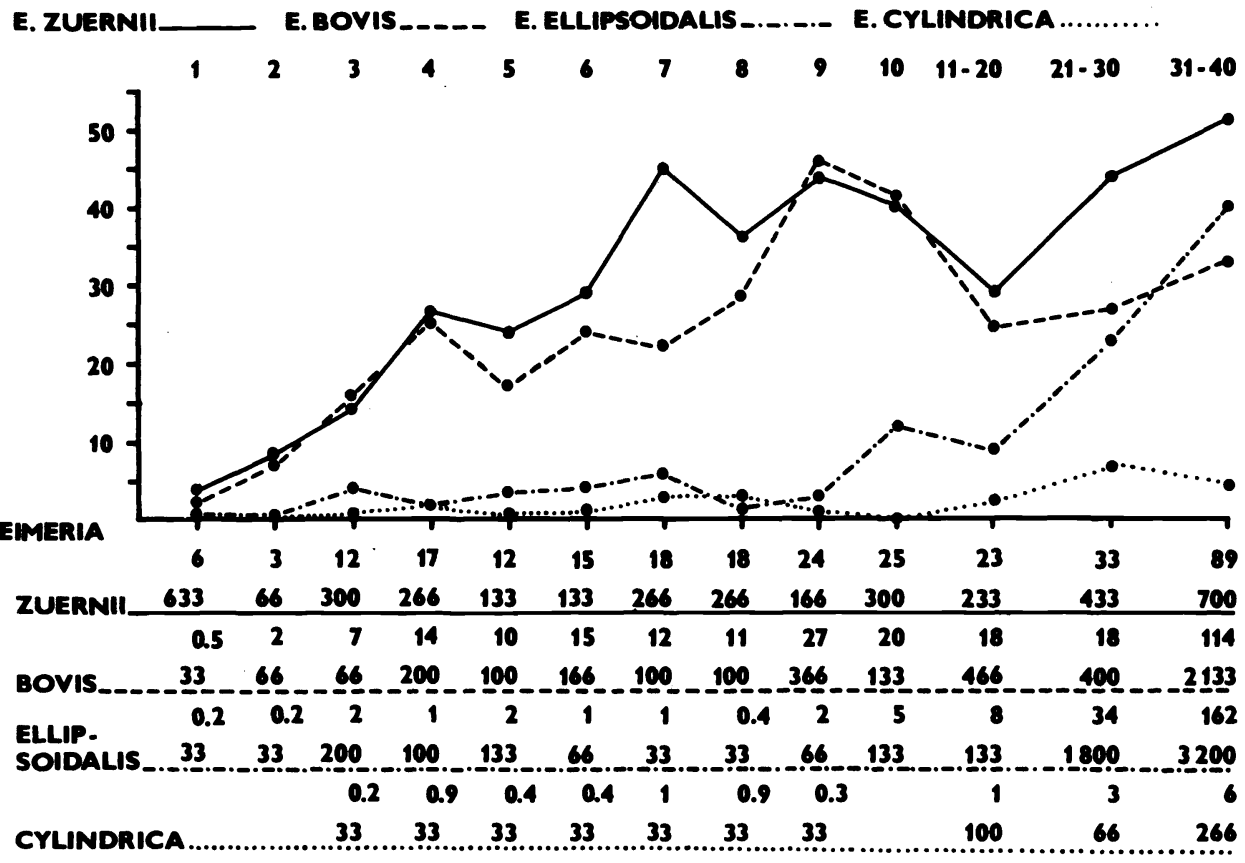

F18. 1

Excretion of oocysts of pathogenic specles of coccidia by calves in calving pens and calf houses.

Numbers and vertical axes Indicate the $Z$ of calves excreting coccidia oocysts. Numbers above the graph ( 1 to 40 ) Indicate the age of calves in days. Short abscissas on the horizontal axis of the graph correspond with the numbers above the graph. In the vertical lines (under numbers 1 to 40 ) and under the polygonal point (indicating the extent of infection) there are numbers giving the intensity of the infection in the same days of age of the calves: above, the average number of oocysts, under it the naximun number of oocysts in 18 of faeces. The numbers of oocysts of 4 coccidia species are given above the same lines indicating the extent of infection with the same specles in the graph. Values were obtsined by examination of 1468 calves in calving pens and calf houses used for a longer perlod. 


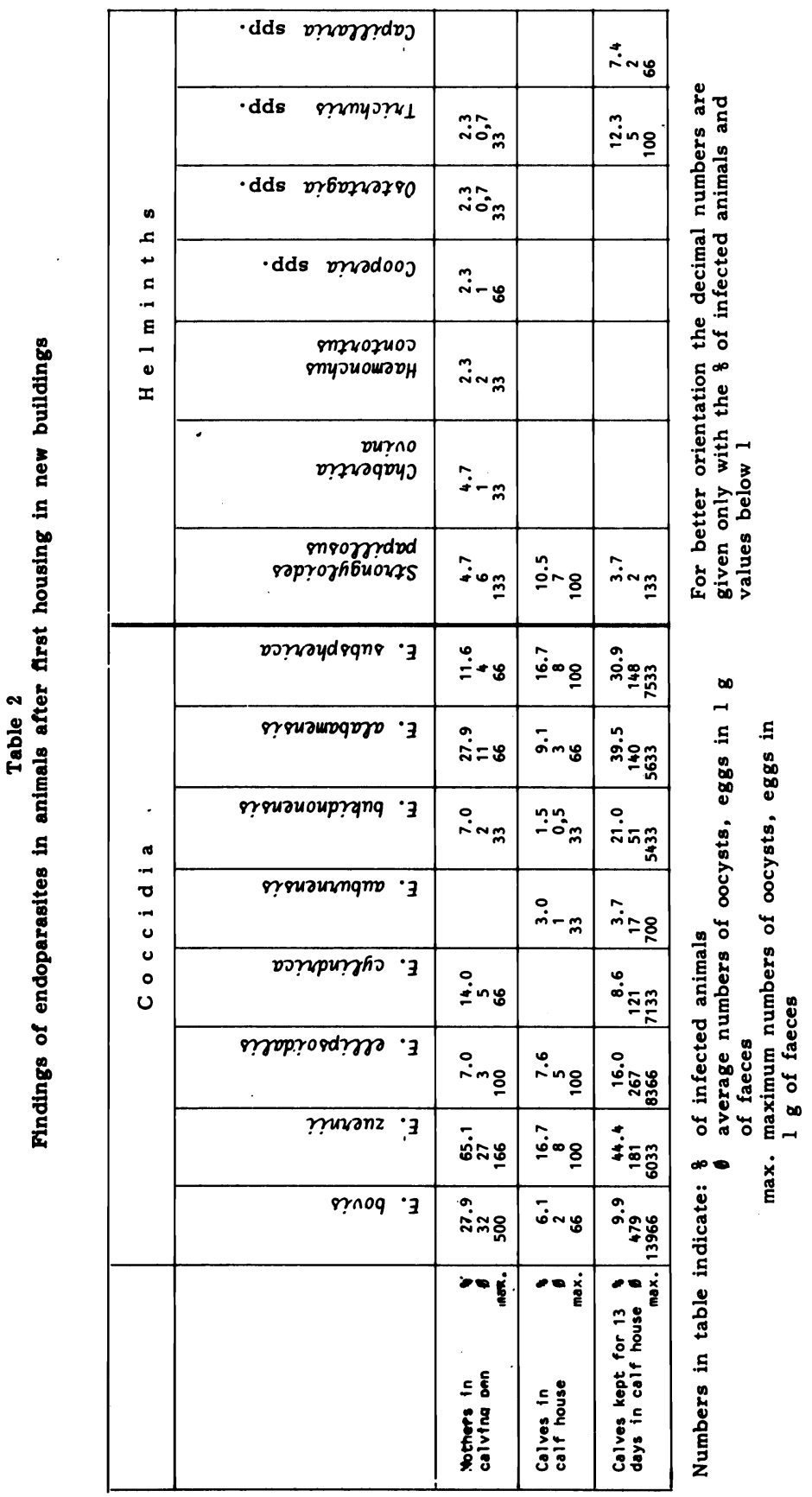




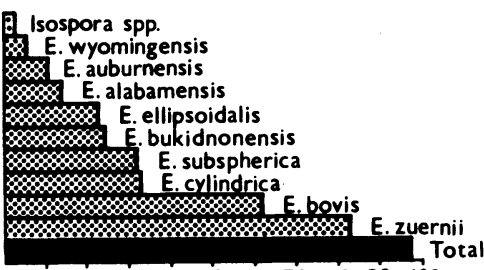

$\begin{array}{llllllllll}10 & 20 & 30 & 40 & 50 & 60 & 70 & 80 & 90 & 100\end{array}$

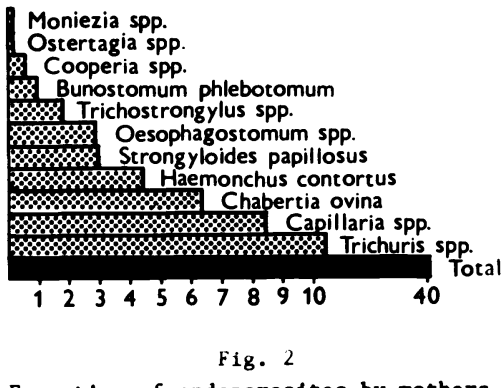

Excretion of endoparasites by mothers.
E. alabamensis

E. bukidnonensis

E. subspherica

E. auburnensis

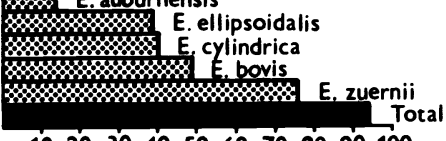

102030405060708090100

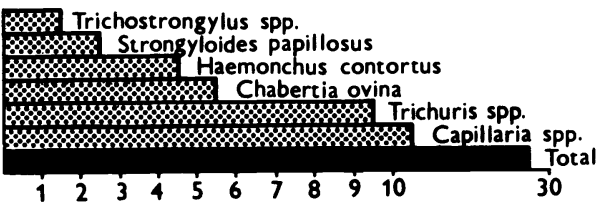

Fig. 3.

Excretion of endoparasites by nurse cows .

White columns indicate the $Z$ of cows excreting the individual coccidia (above) and helminth (below) species Lower black columns indicate the total parasitization of cows with coccidia and helminths. The numbers below indicate the $\bar{z}$ of parasitized animals. Values were obtained by examinations of 800 cows.

Trichostrongylus spp. were found. From the second to the ninth days of age the number of calves excreting coccidia cocysts increased. This increase was remarkable with calves shedding the strongly pathogenic species $E$. zuernii and $E$. bovis. Further increase of the extensity and intensity of coccidial infections appeared after the age of 20 days. The increasing infection rates from the first day of life can be seen from the curves in Fig. 1 and the upper lines of Tab. 1.

After the prepatent period, the extensity of the infection with $E$. zuernii and E. ellipsoidalis expressively increased from the 3rd day of life. The extent of the infection with other coccidia species after the prepatent period did not increase significantly.

In calving pens and calf houses used for a longer time, 42.2 of the calves shed coccidia oocysts: 26.9 \& shed E. zuernii, 21.7 \& $E$. bovis, 7.6 \&

$E$. subspherica, 6.8 E. ellipsoidalis, 4.1 \& $E$. alabamensis, 2.6 \&

$E$. bukidnonensis, 1.9 \& $E$. cylindrica, 1.3 \& auburnensis, and 0.1 \&

$E$. wyomingensis. Only 2.8 \& of the calves shed helminth eggs: 0.9 \& calves shed Trichuris spp., 0.8 Strongyloides papillosus, 0.7 \&apillaria spp., 0.3 \& Haemonchus contortus, 0.2 \& Trichostrongylus spp., and 0.2 \% Oesophagostomum spp.

Since the findings of parasites in the youngest calves were very unusual, their mothers were examined as well. In calving pens used for a longer time, only 2.3 \& of the mothers did not excrete coccidia; 82.8 \& of the mothers excreted $E$. zuernii ocysts, 60.6 \& . bovis, 32.8 \& $E$. cylindrica, 32.1 \& $E$. subspherica, 25.3 \& $E$. bukidnonensis, 22,6 \& E. ellipsoidalis, 13.6 \& $E$. alabamensis, 10.2 \&, E.auburnensis, $5.3 \%$. E. wyomingensis, and 2.5 \& Isospora spp. Helminth eggs were excreted by 41.3 \& of the mothers: 10.5 \& were Trichuris spp., 8.6 \& Capillaria spp., 6.3 \& Chabertia ovina, 4,5 \& Haemonchus contortus, 3.1 \& Strongyloides papillosus, 3.0 \& Desophagostomum spp., 1.8 \& Trichostrongylus spp., 1.1 \& Bunostomum phlebotomum, 0.6 \& Cooperia spp., 0.2 \& Ostertagia spp., and 0.2 \& Moniezia spp.

The infection was heavy also in the nurse cows: 76.5 \& excreted $E$. zuernii oocysts, 49.0 \& E. bovis, 40.5 \& E. cylindrica, 39.0 \& E. ellipsoidalis, 14.0 \& $E$. auburnensis, 11.5 \& $E$. subspherica, 9.5 \& $E$. bukidnonensis, and 6.0 \& $E$. alabamenis. In total, 94. 5 \& of the nurse cows excreted coccidia oocysts. Enterohelminth eggs were excreted by 29.5 \& of the nurse cows: 10.5 \& were Capillaria spp., 9.5 \& Trichuris spp., 5.5 \& Chabertia ovina, 4.5 \& Haemonchus contortus, 2.5 \& Strungyloides papillosus, and $1.5 \%$ Trichostrongylus spp. 
The new buildings were compared with calving pens and calf houses used for a longer time. After introduction into the new calving pen, 88.48 and 16.38 of the first-calvers excreted coccidia oocysts and helminth eggs, respectively. In the new calf house, 36.48 and $10.6 \&$ of the calves excreted coccidia and helminths, respectively. Thirteen days after introduction into the new large-scale calf house, $72.8 \&$ and $17.3 \&$ of the calves were parasitized with coccidia and helminths, respectively. Tab 2 . shows the species and number of parasites. The species composition of the parasites shows the whole spectrum of endoparasites transferred as early as during the introduction of the animals into the new buildings. The strongly pathogenic coccidia species were brought into all new buildings.

Observations of the animals under study showed that the parasitisms were transferred during the time when the calves sucked under their mothers or nurse cows, when they licked and sucked each other, and the walls, pens, stall partitions, pipelines, central heating body, and other objects. The calves housed in the boxes together with mothers were exposed to coccidia and helminths most heavily. Calves housed individually in pens and in separate stanchion pens were found to excrete oocysts sporadically.

Also in the calving pens and calf houses used for a longer time, the majority of calves was not exposed to mass infestations and ingested only smaller amounts of parasites. The numbers given in the last line of Tab. 2 indicate that a great propagation of coccidia occurs in calves transferred into the newly built large-scale calf house. Calves infected in the calving pens and calf houses could be the source of heavy contamination of large-scale calf houses.

\section{Discussion}

As early as in 1964, when there were only a few large-scale calf houses in the Czechoslovak Socialist Republic, C h r o u s t (1964) warned that coccidiosis usually begins in one or a few calves. Light infections are not noticed and the calves become dangerous sources of coccidia. H a m m $0 \mathrm{n} \mathrm{d}$ (1964) drew attention to the fact that coccidiosis in cattle can be gradually caused by a single oocyst. The reproductive potential of Eimeria zuernii is $1: 14000$ and of $E$. bovis it is $1: 250000$ (F u c h s 1983). From the epizootiological point of view, smaller amounts of parasites should also be taken into account because they are able to reproduce rapidly especially in large-scale houses.

$\mathrm{S} v$ a $\mathrm{n}$ b a e $\mathrm{v}$ (1967) found coccidia oocysts on the udders of cows. $\mathrm{Z}$ a $\mathrm{j}$ i$c$ e $k$ et al. (1977) examined heifers and pregnant cows from 25 farms of the supply region of the calf house and on the basis of oocyst findings they reported that: "From the etiological point of view it is necessary to take into account the transfer of coccidia by calves from their maternal houses." Our findings in calves soon after birth fully confirm these opinions. $Z$ a j $i$ $\subset$ e $k$ (1982) draws attention to the fact that at the present time the problem of clinical diseases caused by coccidiosis is coming to the fore in large-scale calf houses; in some districts in Bohemia, as many as $0.14-15.12$ of of calves from the housing suffered from coccidiosis, 5 - 1008 of which died. The species $E$. zuernii and $E$. bovis were found to predominate in large-scale calf houses of the industrial type. Both species,

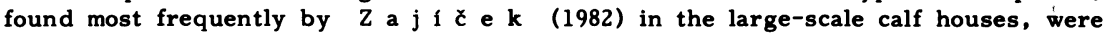
the most frequently found in calving pens and calf houses in the present study. $E$. bovis oocysts sporulate 2 - 3 days, those of $E$. zuernii $3-4$ days. In the modern large-scale buildings they become infective very quickly.

P a v lá s e $k$ (1982) examined 380 dairy cows on 11 farms from which the calves were transferred into a new central calf house, and he found coccidia in all these farms. In the newly opened large-scale calf house, the calves of the first housing shed coccidia oocysts in the third week after transfer, calves of the 4th housing already in the first week. It was found that the longer the operation of the calf house, the shorter the period of a 1008 infection of the calves. S $t$ e i nb a c h (1982) diagnosed clinical coccidiosis in new calf houses 4 months after the houses where calves were fed on starters were fully occupied; he considered the source of coccidiosis to be the region from which the calves were transferred.

$S$ v a $n$ b a e $v$ (1967) observed first coccidia oocysts in a 10-day-old calf. P r $0 k \circ p i c$ and $P$ a v l á $\mathbf{s}$ (1977) found sporadic Eimeria bovis oocysts in a 12-day-old calf. Coccidia oocysts of the genus Cryptosporidium, not found in 
Czechoslovakia until 1980, were excreted much earlier than coccidia oocysts of the genus Eimeria ( $\mathrm{P}$ a v lás e $k$ 1981). L u k e š o vá et al. (1984), P a v lá s e $k$ et al. (1983) found Cruptosporidium sp. oocysts in calves of only 3 days of age; at the farm under study, all the 6 to 14-day-old calves were excreting Cryptosporidium sp. oocysts. P a v lás e $k$ et al. (1983) studied the effect of different housing of the calves after birth on the occurrence of Cryptosporidium sp. They found these coccidia in all the housing types in all the calves but no significant effect of the system of housing on the occurrence of Cryptosporidium infections was proved.

$S$ t e i $n$ et al. (1983) found 5 million Cryptosporidium sp. oocysts in $1 \mathrm{~g}$ of calf faeces as early as on the first day of the patent period. In the naturally infected calves they found as many as 74 million oocysts in $1 \mathrm{ml}$ of faeces. F i s c h e $r$ (1984) reported that: "... it is true that coccidia of the genus Cryptosponidium are very frequent in calves, especially from the 5 th till 30 th day of life, but are not expressively manifested in large-scale houses because most of the infections die out with the increasing age of the calves." $M$ e $n \leq i$ k et al. (1984) drew attention to the fact that the significance of cryptosporidia as primary pathogens has not yet been conclusively explained, "... it seems that they could be a facultative pathogen because they firmly adhere to the epithelial cells of the intestinal mucosa... and damage the microvilli."

The endogenous stages of coccidia of the genus Eimeria (often found in the present material) develop mostly in the superficial layer of the intestinal mucosa. Schizonts and sexual stages of $E$. zuernii parasitize in the epithelial cells of the small and large intestines and the caecum and they are, on average, $11-14 \mu \mathrm{m}$ large ( $\mathrm{a} v \mathrm{i} s$ and $\mathrm{B}$ o $\mathrm{w} \mathrm{m} \mathrm{n}$ 1957).E. bovis forms relatively large schizonts - on average $300-400 \mu \mathrm{m}$ - in the endothelial cells of the villi of the small intestine. The second generation of schizonts is localized in the caecum and large intestine ( $\mathrm{H}$ a m m $\mathrm{m}$ d 1964). Endogenous stages of $E$. bovis and $E$. auburnensis in the intestines penetrate into the propria mucosae ( $G$ r a $\ddot{a}$ f $n$ e $r$ and $G \mathbf{r}$ a $\mathrm{b} \mathbf{m}$ a $n$ 1979). In some Eimeria species parasitizing in cattle, the endogenous development is not yet known. Coccidia of the genus Eimeria often considerably damage the intestinal mucosa and thus allow the various microorganisms to penetrate.

M e n S i k et al. (1984), as well as other authors, report that the diseases occuring in the course of intensive calf rearing are, as a rule, due to the co-action of many microorganisms. From the present results it is evident that calves are parasitized as early as in the calving pens and calf houses.

Calves in which the parasites were found, frequently licked the surrounding objects and other calves. Various authors (e.g. H i n t n a s 1978) drew attention to the fact that mutual licking of calves is a mass phenomenon in large-scale herds due to the fact that calves were taken away from their mothers very early and

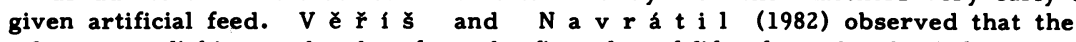
calves start licking each other from the first day of life, from the third day they begin to suck each others ears, umbilical stump and genitalia. This mutual licking and sucking was found to become more frequent in calves placed into a common pen after birth. In calves housed in byres with stanchions and in groups, as well as in calves housed in individual pens, the frequency of licking increased with age. Calves suffering from diarrhea licked the walls very intensively and for a very long time (because of thirst due to dehydration). N $\mathrm{i} 11_{1}^{\circ}$ (1970) noted that oocysts in the faeces sticking to the hair coat of the cattle can sporulate due to the effect of body temperature and infect the animal licking its body surface. In the present material, from the second day of age, the number of calves excreting oocysts of $E$. zuernii and $E$. bovis (see Fig. 1), very widely spread in large-scale herds, increased. It is evident that frequent licking of various surfaces as well as licking each other brings the infective agents into the calves' alimentary tract.

Observations of the calves examined in the present study showed that the parasites are transferred already due to insufficient cleaning of the oral cavity during post-parturition treatment and due to insufficient treatment of the calves mainly during night parturitions, on Sundays, and when the attendants are being relieved. Dirty hair coat of the cows in litter-free calving pens affects the hygiene of parturition and may contaminate the environment. The work of the attendants greatly influences the transfer of parasites in calving pens and calf houses, especially when technological 
and hygienic rules are not observed. In the present material, sometimes the endoparasite species of the mother did not agree with that of her own calf, but among the calves and other mothers in the same calving pen they did. From conforming findings of various farms it is evident that large-scale buildings are contaminated with endoparasites already at the beginning of operation and that the source of infection are not only the true mothers. The present results showed that the transfer of coccidia into the alimentary tract of the animals cannot be prevented at the present time under operational conditions. Clinical disorders are most frequently produced by a larger number of parasities that could be effectively limited when establishing "all in - all out" systems of housing.

Measures aimed at control of endoparasite transfer are similar to those aimed at prevention of bacterial and viral contamination of premises. It is a must to observe the hygiene of udder, cleanness of the vessels from which the calves drink, to keep the floor clean and to change the litter in the boxes of the calves very regularly. Faeces should be removed especially from the surfaces licked by the calves.

$\mathrm{J}$ e h 1 i $C_{\mathrm{K}} \mathrm{a}$ (1966) noticed a sucking reflex which lasted for 30 minutes after the calf drank milk. He reccomends that the calves be fixed for about half an hour after drinking milk until the sucking reflex disappears. P o 1 a $k$ (1980) and other authors recommended the "all in - all out" system of housing for calf houses as well. $M$ e $n$ s $1 \mathrm{k}$ et al. (1983) recommended calving pens with this operation in isolated sections. They recommend that the calf house be divided into a larger number of separate sections, or at least into two parts, with alternating operation in order that the free part could be disinfected, and to house the calves into individual boxes. $\mathrm{K} r \mathrm{e} j \mathrm{C} \mathrm{i}$ et al. (1984) and other authors propose similar measures. The measures proposed are very convenient also for reducing the transfer of endoparasites in calving pens and calf houses. Coccidia oocysts and helminth eggs are very resistant to various disinfectants. That is why regular and thorough mechanical cleaning removing most of the parasites is so important.

$\mathrm{H} \circ \mathrm{j} \circ \mathrm{vec}$ et al. (1973) drew attention to the fact that the preventive measures should be aimed, in the first place, at increasing the specific resistance of the calves even before transport into large-scale calf houses. Repeated examinations showed that the majority of mothers and nurse cows are virtually permanently parasitized with coccidia (frequently with several species). The nearly permanent presence of endoparasites in the organism enables to obtain and maintain antiparasitary immunity of the mothers and to form conditions for colostral immunity of the calves. Small doses of parasites create conditions for the development of defence mechanisms as early as in the very young calves.

In the present material from various calving pens and calf houses, coccidia of the genus Eimeria were found in very low intensities, helminths only sporadically. It is improbable that the endoparasites mentioned would be of greater importance in diarrheal disorders of newborn calves. More important is the transfer of coccidia from calving pens and calf houses into large-scale calf houses.

\section{Infikováni telat endoparazity $v$ porodnách a profylaktorích}

Telata jsou infikována kokcieliemi a helminty již při porodním ošetroování, sání a olizování. Zdrojem nákazy jsou matky a kojné krávy. V déle používaných porodnách vylưovalo 97,7 \& matek kokcidie, silnè patogenní druhy Eimeria zuernii 82,8 \& , $E$. bovis 60,78 , helminty vylucovalo 41,38 matek. V porodnách a profylaktorifich už́vaných více let vylučovalo 42,2 \& telat kokcidie: 26,9 \& $E$. zuernii, 21,7 \& $E$. bovis a 2,8 \& helminty. Byla sledována kontaminace nove vybudovaných objektů při uváděni do provozu: Po zavedení do otevírané porodny vylučovalo 88,4 \& prvotelek kokcidie a 16,3 \& helminty. V novém profylaktoriu vylučovalo 36,4 \& telat kokcidie a 10,68 helminty. Za 13 dnú po naskladnění do nového velkokapacitního teletníku bylo jiz 72,8 \& telat parazitováno kokcidiemi a 17,3 \& helminty.

Již z poroden a profylaktorí se šruri druhy endoparazitú (jsou uvedeny ve výsledcích), kterým ekologicky vyhovuje stájové prostředí. Silnè patogenní druhy kokcidii byly shodně zjištovány ve vక̌ech sledovaných objektech. Kokcidie přenášejí zejména slabá, starši telata, která bývaji ponechávána déle $v$ profylaktorif́ch. Při dodržování technologické a hygienické káznè turnusového zástavu je množství parazitárních agens pr̆́liš̌ malé $k$ vyvoláni klinickych př́znakú, ale umožnuje rozvoj obran- 
ných mechanismů velmi mladých telat. Při nedodržování hygieny se znařně zvyšuje množství oocyst, které mohou pưsobit klinické kokcidiózy.

\section{Инвазия телят эндопараэитами в родильных помешениях и профилахториях}

Телята инфицированы хохцидиами и гельминтами уже в период послеродого ухода, сосания и облизывания. Источником заражения являются матхи и хоровы-хормилицы. В длительное время используемых родильных помещениях 97,7 матох выделяли хохцидии, 82,8 интенсивно патогенные виды Eimeria zuernii, 60,7 - E. bovis, гельминты выделяли 41,3 ватох. В находящихся в эхсплуатации в течение нескольких лет ғодильных помемениях и профилахториях 42,2 телят выделяди хохцидии: 26,9 - E. zuernii, 21,7 E. bovis и 2,8 - гельминтов. Проводились исследования хонтаминации вводимых в эхсплуатацию новых объехтов: в упомянутых объехтах 88,4 в новотельных хоров выделяли кохцидии и 16,3 \& - гельминты. В новом профилахтории выделяли 36,4 \& телят хохцидии и 10,6 - гельминты. Через 13 сутох после занятиа нового хрупного телятниха уже 72,8 г телят были заражены хохцидиями и 17,3 - гелминтами.

Уже из родильных помещенй и профилахториев распространяются виды ендопаразитов (они приведены в результатах), для хоторых экологически приемлема стойовая среда. Патогенные виды хохцидий были аналогично выявлены по всех исследуемых объехтах. Передатчихами хохцидиев являются особенно слабые телята старшего воэраста, находящиеся длительное вреия в профилахторня . При соблюдении технологической и санитарно-гигиеничесхой дисциплины численность паразитарных ахтивных фахторов незначительна для того, чтобы вызвать проявления хлинических приянахов, но она способствует развитию эащитных мехавиямов телят раннего воэраста. При несоблюдении гигиены эначительно увеличивается число ооцистов, хоторые могут вызвать хлиничесхий хохцидиоз.

\section{Re ferences}

BEJŠVEC, J.: Discharge of oocysts coccidla by young calves in the prepatent period. J. Protozool., 30, 1983: 29 A.

BREZA, M.: Some practical knowledge and suggestions to the helminthcoprologic diagnost1c. Helminthologia, 1, 1957: 57-63. (In Slovak).

BREZA, M. - ŚVARC, R.: Eine elnfache Methode zur Bestimmung der Einzahl gastrointestinaler Strongylaten in den Faeces der Wiederkäuer. Studia Helmintol. Košice, 1967. CHROUST, K.: Kokcidióza u telat. Coccidiosis in calves. Acta univ. agric. Brno, B 12, 1964: 209-223.

DAVIS, L.R. - BOWMAN, G.W.: The endogenous development of Eimeria zuernit, a pathogen1c coccidium of cattle. Am. J. Vet. Res., 18, 1957: 569-574.

HOJOVEC, J. - KRAITR, J. - MARKOVIC, P. - PYTLOUN, J. - SRAMEK, J. - MENSIK, J. HAVELIK, J. - VANA, V. - VRBICANOVA, M. - ANTAL, J. - BLAHO, R. - HUBINSKY, J. MEDVECKY, J. - KOUBEK, J.: Odchov telat ve velkokapacitnich teletnícich. Metodiky CSAZ OVTI Praha 1973, p. 31.

FISCHER, 0.: Ekonomický význam kokcidí rodu Cryptosporidium pro odchov telat. Vet. med. Praha, 29, 1984: 419-424.

FUCHS, G.: Díe. Bedeutung der Kokz1diose für die Kälber- und Jungrinderaufzucht sowle Massnamen zu threr Verhütung (Sta11/We1de). Tierzucht, 37, 1983, 441-443.

GRXFNER, G. - GRAUBMAN, H.D.: Betrachtungen zur Pathogenität von Eimeria-Arten am Beispiel der Rinderkokzidiose. Angew. Parasit., 20, 1979: 202-209.

HAMPOND, D.M.: Coccidiosis of cattle; some unsolved problems. 30th Fac. Honor. Lech., Utah State Univ., Logan, Utah. 1964, p. 36.

HINTNAUS, J.: Nové aspekty $v$ etłologi1 sání respektive samosání mléka u dospělých plemenic skotu. Referát na 5. etologické konferenci N1tra 25.4.1978.

JEHLICKA, L.: Poznatky z etologie telat ve velkokapacitnich teletnících. Otázky etologie hospodářských zvíłat ve velkovýrobních podaínkách. Praha, OVTI, 25, 1966: 50-60.

RREJCI, J. - KUNC, D. - HRABẼ, J. - SIP, J.: Prevence ztrát telat v systému otevřeného obratu stáda skotu. Veterináf́stvi, 34, 1984: 56-59.

LUKESOVA, D. - NEVOLE, J. - DANICKOVA, H. - SALAMOUNOVA, Z. : Možnost1 laboratorní diagnostiky kryptosporidiözní invaze u telat. Veterináfství, 34, 1984: 536-538. 
MACKO, J.K.: On helminth propagation by transit of invasive elements through definitive and intermediate hosts. Helminthologia Bratislava, 16, 1979: 127-140.

MACKO, J.K.: On the grounds of transit of helminth invasive stages through the digestive tract of hosts with reference to the definitive hosts (s.I.). Helminthologia, Bratislava, 17, 1980: 49-55.

MENSIK, J. - PSIKAL, I. - MADR, V. - STEPANEK, J. - POSVAROVA, M. - TOMAN, M. FRANZ, J. - VALOSKOVA, P. - PECKA, F. - JURMANOVA, K. - SALAJKA, F. - VALIČ́EK, L. SMID, B. - KRECHLER, P. - KOHOUT, V. - KURIAL, J.: Model komplexní prevence ztrát telat na velkokapacitních farmách ve složitých epizootologických podmínkách. Profect Report, Veterinary Research Inst1tute, Brno, 1983, p. 39.

MENSTK, J. - POSPIŠIL, Z. - STËPNEK, J. - JURAK, E. - MADR, V.: Současná epizootologická situace $v$ intenzivních chovech skotu $v$ souvislosti s nemocností a mortalitou telat v průběhu jef1ch odchovu. Vet. Med. Praha, 29, 1984: 47-64.

NILLO, L.: Bovine coccidios1s in Canada. Can. Vet. J., 4, 1970: 539-548.

PAVLASEK, I.: First record of Cryptosporidium sp. In calves in Czechoslovakia. Folia par., Praha, 28, 1981: 187-189.

PAVLASEK, I.: Dynamika výskytu kokcidí u čtyř zástavủ telat ve velkokapacitním teletníku Stará Hlína. Vet. Med., Praha, 27, 1982: 199-208.

PAVLÁSEK, I. - ZIKMUND, B. - KLIMA, F.: V11v rúzného zpủsobu ustájení telat po narození na výskyt Cryptosporid1um sp. Vet. Med., Praha, 28, 1983: 31-36.

POLAK, L.: Současná situace $v$ odchovu telat ve velkokapacitních teletnících v podmínkách CSR. Sborník Problémy odchovu telat ve velkokapacitních teletnících.vSZ Praha, 1980: 4-14.

PROKOPIC, J. - PAVLASEK, I.: Endoparazit1 telat ve velkochovech. Vet. Med. Praha, 22, 1977: 505-512.

STEIN, E. - BOCH, J. - HEINE, J. - HENKEL, G.: Der Verlauf natürlicher Cryptosporidium-Infektionen 1i vier Rindzuchtbetrieben. Ber1. Münch. T1erärzt1. Wschr., 96, 1983: 222-225.

STEINBACH, J.: Kokc1d1öza a ostatní onemocnění telat. Informační zprávy pro veterinární a zemědělskou praxi SPOFA 1, 1982: 26-31.

SVANBAEV, S.K.: Kokcidil svinej 1 krupnogo rogatogo skota v Kazachstane. An. Kaz. SSR, Trudy Inst. zoo1., 28, 1967: 93-128.

VĚ̌̉s, J. - NAVRATIL, J.: Chování telat v období po porodu v závislosti na zpủsobu ustáfení. Sborník Vys. školy zemědělské v Praze, B, 37, 1982: 109-124.

ZAJICEK, D. - BISCHOFOVA, N. - SANDA, V. - FOJTIR, V.: Výskyt kokcid1i u telat ve ve1kochovu. Veterı́nárství, 27, 1977: 507-508.

ZAJICEK, D.: Ep1zootologie kokcidiözy telat. Informační zprávy pro veterinárni a zemědělskou praxi SPOFA, 1, 1982: 7-12. 